\title{
Content and Accumulation of Macronutrients in Radish Seeds in Response to Sulfur and Organic Compost
}

\author{
Ariel Santivañez Aguilar, Henrique Vasque, Estefânia Martins Bardiviesso, Andres Felipe \\ Gaona Acevedo, Ricardo Adriano Felito, Raíra Andrade Pelvine, Sara Raissa Brito Bezerra, \\ José Murillo de Oliveira Leis, Antonio Ismael Inácio Cardoso \\ Department of Horticulture, School of Agriculture (FCA), São Paulo State University \\ (UNESP), Botucatu, São Paulo state, Brazil \\ Ernane Miranda Lemes \\ Institute of Agrarian Science (ICIAG), Federal University of Uberlândia (UFU), Uberlândia, \\ Minas Gerais state, Brazil. E-mail: ernanefito@gmail.com
}

Received: December 14, 2020

Accepted: August 3, $2021 \quad$ Published: August 9, 2021

doi:10.5296/jas.v9i3.18064

URL: https://doi.org/10.5296/jas.v9i3.18064

\begin{abstract}
Sulfur (S) is usually the second most accumulated nutrient in seeds of Cruciferae plant species such as the radish. Tropical soils have low $\mathrm{S}$ availability creating a challenge to manage plant nutrition and balanced plant development to produce high-quality seeds. This study evaluated the influence of S doses and organic compost fertilization on the content and accumulation of macronutrients in radish seeds. Eight treatments were studied in subdivided plots, where the presence $\left(50 \mathrm{t} \mathrm{ha}^{-1}\right)$ or absence of organic compost was placed in the main plot, and the $\mathrm{S}$ doses $\left(0,60,120,180 \mathrm{~kg} \mathrm{ha}^{-1}\right.$ of $\left.\mathrm{S}\right)$ were placed in the subplots. A randomized block design with six replications was used. Seed dry weight, N, P, K, Ca, Mg, and S concentration ( $\mathrm{g} \mathrm{kg}^{-1}$ of dry matter), and the accumulation of nutrients in seeds $\left(\mathrm{g} \mathrm{plant}^{-1}\right)$ were evaluated. There was no significant effect of $S$ doses, or organic compost, on the contents of macronutrients in radish seeds. When organic compost was not applied, great doses of S generated great dry weight and accumulation of macronutrients in the radish seeds. However, the application of organic compost increased the dry weight and the accumulation of all macronutrients in radish seeds in low S doses (up to $66 \mathrm{~kg} \mathrm{ha}^{-1}$ ). Also, the presence of organic compost increased the dry weight and the concentration of macronutrients in radish seeds. The decreasing order of macronutrient content and accumulation by the radish seeds was: $\mathrm{N}>\mathrm{S}>\mathrm{K}>\mathrm{P}>\mathrm{Ca}>\mathrm{Mg}$.
\end{abstract}

Keywords: Raphanus raphanistrum, composted cattle manure, dry seed mass, nutrient decreasing order 


\section{Introduction}

Radish (Raphanus raphanistrum subsp. sativus) is a plant species propagated by seeds with direct sown, not tolerating seedling transplants. The seed cost is very high because 10 to 20 $\mathrm{kg} \mathrm{ha}^{-1}$ of seeds are necessary for commercial fields. The use of seeds of high physiological quality, germination, and vigor is fundamental to dilute costs and obtain a uniform plant population. The efficient management of crop fertilization improves the production of larger quantities of high-quality seeds. For vegetable species, the amount of nutrients for seed production is different from those used for commercial production due to a longer development cycle (Magro et al., 2012).

In Brassicaceae plant species, sulfur (S) supply is required between 70 and $80 \mathrm{~kg} \mathrm{ha}^{-1}$, a dose much higher than the recommendation for most crops, between 15 and $50 \mathrm{~kg} \mathrm{ha}{ }^{-1}$ (Alvarez-Venegas et al., 2007). In many Brazilian soils, such as Oxisols and Ultisols, there is low natural S availability to plants (Pereira et al., 2016). Sandy soils with low organic matter content also raise the necessary $S$ doses (Tiecher et al., 2013). The liming and fertilization practices with surface soluble phosphates cause the migration of $\mathrm{SO}_{4}{ }^{-2}$ to deep layers, limiting access by the roots (Rheinheimer et al., 2005), favoring S deficiency (Caires and Fonseca, 2000). In addition, in the last decades, the appearance of $S$ deficiency symptoms has been increasing in the crops by the increase of concentrated fertilizers without S (Melo et al., 2011; Sun et al., 2017).

Usually, the organic matter present or added to the soil is the main source of $S$ to the plants (Fernandes, 2006), indicating that $\mathrm{S}$ can be applied in lower amounts when organic fertilization is used in large quantities. However, these large quantities are not always available, and they can be more expensive than inorganic fertilizers. One option would be using a S-containing nitrogen source, such as ammonium sulfate, in topdressing fertilization.

In seed production, the nutritional requirement becomes more intense during the reproductive phase (Cardoso, 2011; Carvalho and Nakagawa, 2012), and fertilization at this stage improves seed production and quality. Also, organic fertilization can meet the nutritional requirements at this stage by the slow release of nutrients (Magro et al., 2012). The supply of organic compost during sowing increased the production of broccoli (Brassica oleracea var. italica) and lettuce (Lactuca sativa L.) seeds (Magro et al., 2010; Quadros et al., 2012), and the S supply positively affected the production of broccoli seeds. However, there is still a significant lack of information related to nutritional recommendations for seed production.

In Brassicaceae seeds, such as broccoli (Magro et al., 2010) and cauliflower (Cardoso et al., 2016), $S$ is the second most accumulated nutrient in seeds. As a Brassicaceae, radish may also have great $\mathrm{S}$ demand for seed production. Also, the cycle for seed production is much longer than the cycle for market production of roots, indicating that the extraction of nutrients can be much superior when radish is destined for seed production. Since no research was found about the content and accumulation of macronutrients in radish seeds, the objective of this work was then to evaluate the influence of $\mathrm{S}$ doses and fertilization with organic compost on the content and accumulation of macronutrients in radish seeds. 


\section{Method}

The experiment was implemented at the São Manuel Experimental Farm located in the municipality of São Manuel, São Paulo state, Brazil. The climate of the region, according to the Köppen classification, is type Cfa, presenting a hot temperate (mesothermic) humid climate, with concentrated rains from November to April. The average annual precipitation of the municipality of $1,376 \mathrm{~mm}$, and the average temperature of the warmest month is higher than $22{ }^{\circ} \mathrm{C}$ (Cunha and Martins, 2009). The geographic coordinates of the area are $22^{\circ} 46^{\prime} \mathrm{S}$ latitude, $48^{\circ} 34^{\prime} \mathrm{W}$ longitude, and about $740 \mathrm{~m}$ above sea level.

\subsection{Soil Characteristics}

The soil of the experimental area is a Typical Red Dystrophic Latosol. Before the installation of the experiment, the chemical analysis was performed in the $0-20 \mathrm{~cm}$ depth layer, with the following results: $\mathrm{pH}\left(\mathrm{CaCl}_{2}\right)=5.5$; organic matter $=12 \mathrm{~g} \mathrm{dm}^{-3} ; \mathrm{P}=94 \mathrm{mg} \mathrm{dm}^{3} ; \mathrm{H}+\mathrm{Al}=18$ mmol $_{\mathrm{c}} \mathrm{dm}^{-3} ; \mathrm{K}=1.9 \mathrm{mmol}_{\mathrm{c}} \mathrm{dm}^{-3} ; \mathrm{Ca}=29 \mathrm{mmol}_{\mathrm{c}} \mathrm{dm}^{-3} ; \mathrm{Mg}=5 \mathrm{mmol}_{\mathrm{c}} \mathrm{dm}^{-3} ; \mathrm{S}=3 \mathrm{mg} \mathrm{dm}^{-3}$; sum of bases $(\mathrm{SB})=36 \mathrm{mmol}_{\mathrm{c}} \mathrm{dm}^{-3}$; cation exchange capacity $(\mathrm{CEC})=54 \mathrm{mmol}_{\mathrm{c}} \mathrm{dm}^{-3}$ and base saturation $(\mathrm{V})=66 \%$.

\subsection{Conduction of the Experiment}

Eight treatments were studied in subdivided plots, where the presence $\left(50 \mathrm{t} \mathrm{ha}^{-1}\right)$ or absence of organic compost was placed in the main plot, and the $S$ doses $\left(0,60,120,180 \mathrm{~kg} \mathrm{ha}^{-1}\right.$ of $\left.\mathrm{S}\right)$ were placed in the subplots. A randomized block design with six replications was used. The organic compost was manually incorporated 15 days before radish sowing at the recommended dose (Raij et al., 1997) for radish production $\left(50 \mathrm{t} \mathrm{ha}^{-1}\right)$. The results of chemical analysis of the organic compost (composted cattle manure) - expressed as percentage (\%) - were: $\mathrm{N}=0.7 ; \mathrm{P}_{2} \mathrm{O}_{5}=1.0 ; \mathrm{K}_{2} \mathrm{O}=0.7 ; \mathrm{Ca}=6.8 ; \mathrm{Mg}=0.4 ; \mathrm{S}=0.4$; humidity $65{ }^{\circ} \mathrm{C}=22 \%$; organic matter $=24 ; \mathrm{C}($ total $)=13$. Ammonium sulfate $(20 \% \mathrm{~N}$ and $23 \% \mathrm{~S})$ was used as the $\mathrm{S}$ source in topdressing fertilization [0 (control), 60, 120, $180 \mathrm{~kg} \mathrm{ha}^{-1}$ of $\mathrm{S}$ ]. Considering that the highest $\mathrm{S}$ dose $\left(180 \mathrm{~kg} \mathrm{ha}^{-1}\right.$ of $\left.\mathrm{S}\right)$ also applied $156.4 \mathrm{~kg} \mathrm{ha}^{-1}$ of $\mathrm{N}$, this dose of $\mathrm{N}$ was complemented in the other treatments with urea $(45 \% \mathrm{~N})$.

The sowing happened on April 12, 2017, using the cultivar Vip Crimson Special Selection. Each experimental plot was composed of three rows spaced $0.7 \mathrm{~m}$ and $1 \mathrm{~m}$ long. The spacing between plants, after seedling thinning, was $0.05 \mathrm{~m}$. At the beginning of the bolting (August 04, 2007), the first topdressing fertilization was carried out with $S$ and nitrogen $(N)$ fertilizers and repeated every seven days, totalizing six applications; thus, 1/6 of the total recommended dose was used in each topdressing fertilization.

\subsection{Characteristics Measured}

At 188 days after sowing, the seeds of 10 plants from the central planting line of each plot were harvested. The extraction process was done manually, and seeds were cleaned to remove impurities, damaged and empty seeds by a density separator, following the methodology of Cardoso et al. (2016). Only the processed seeds (cleaned seeds) were used for the evaluations. 


\section{Macrothink Institute ${ }^{\text {TM }}$}

The seeds were dried in an oven with forced air circulation at $65^{\circ} \mathrm{C}$ until reaching a constant weight. After determining the dry weight of seeds per plant, they were ground. The determination of the content of $\mathrm{N}$ was by sulfuric digestion. For the determination of phosphorus $(\mathrm{P})$, potassium $(\mathrm{K})$, calcium $(\mathrm{Ca})$, magnesium $(\mathrm{Mg})$, and $\mathrm{S}$ was used nitric-perchloric digestion, according to the methodology described by Malavolta et al. (1997). The N, P, K, Ca, Mg, and S contents ( $\mathrm{g} \mathrm{kg}^{-1}$ of dry matter) were determined by the chemical analysis. The accumulated content of nutrients in the radish seeds was determined by multiplying the content of each nutrient to the dry weight of the seeds produced per plant.

\subsection{Statistical Analyses}

The results of the variable studied were submitted to the analysis of variance $(\mathrm{p}<0.05)$. Regressions ( $\mathrm{p}<0.05$ and $\mathrm{R}^{2}>70 \%$ ) were used to study the effect of the doses of sulfur in topdressing fertilization, and the Tukey's test of average ( $p>0.05)$ was used to study the effect of the organic compost applied. The analyses were performed using the Sisvar ${ }^{\circledR}$ statistical software (Ferreira, 2011).

\section{Results and Discussion}

\subsection{Seed Dry Weight}

The seed dry weight per plant presented significant interaction between factors ( $\mathrm{S}$ and organic compost). When no organic compost was added, a linear increase of the dry seed weight per plant was observed with a rise in the $S$ dose (Figure 1). There was a $73.6 \%$ increase in dry weight at the highest $S$ dose $\left(180 \mathrm{~kg} \mathrm{ha}^{-1}\right)$ compared to the control $\left(0 \mathrm{~kg} \mathrm{ha}^{-1}\right)$.
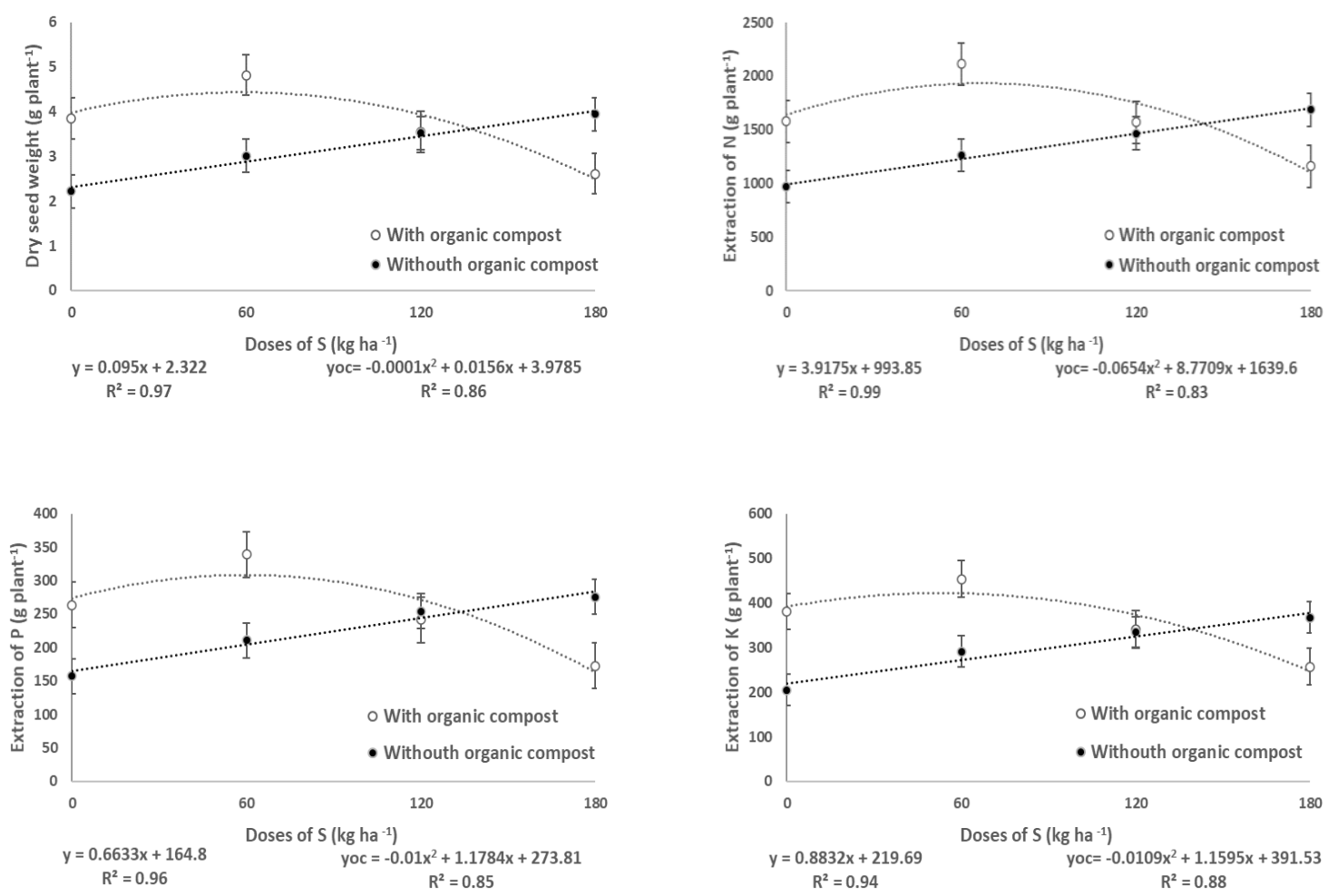

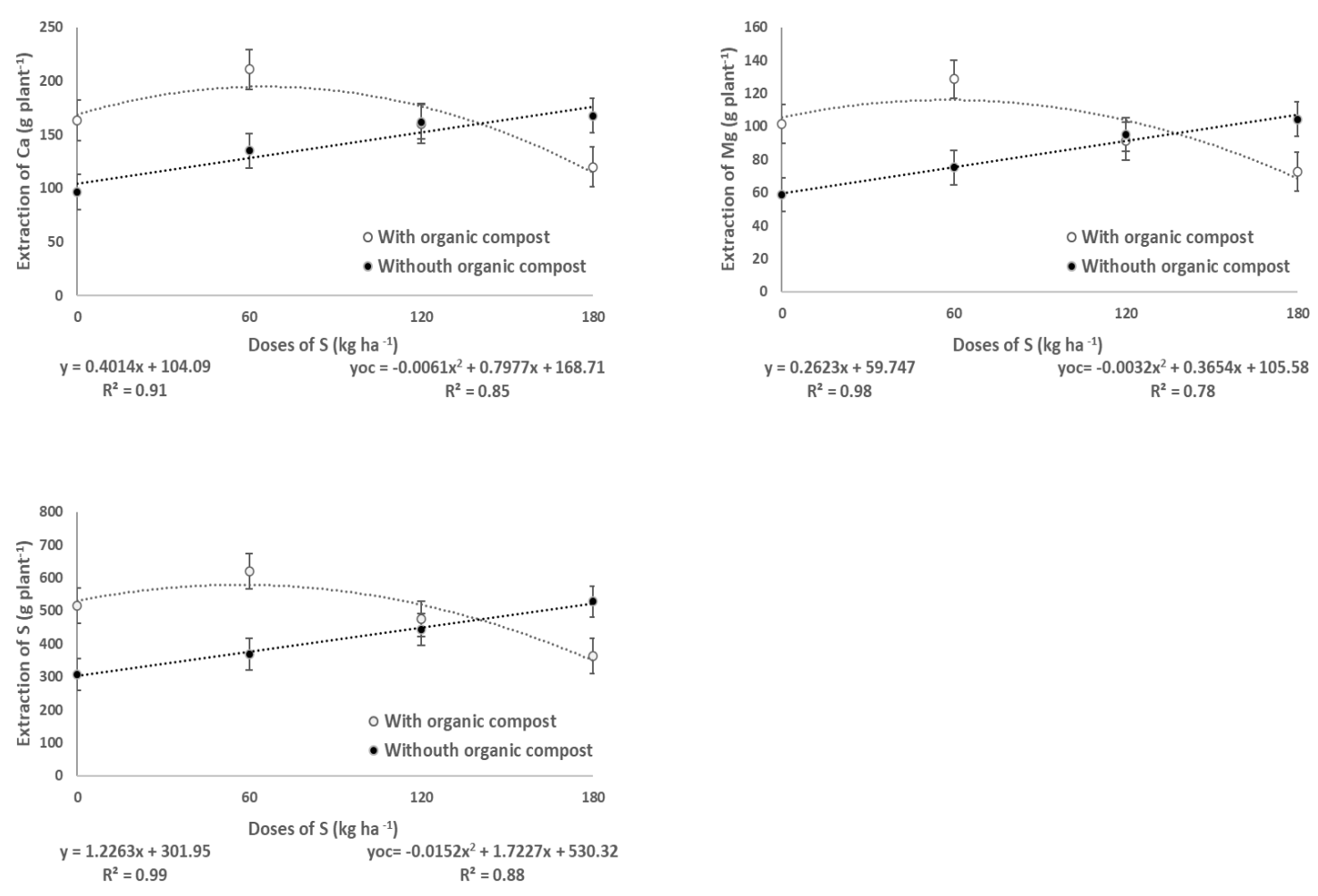

Figure 1. Dry seed weight and nitrogen $(\mathrm{N})$, phosphorus $(\mathrm{P})$, potassium $(\mathrm{K})$, calcium $(\mathrm{Ca})$, magnesium $(\mathrm{Mg})$, and sulfur $(\mathrm{S})$ accumulation in radish seeds per plant as a function of $\mathrm{S}$ doses with or without the application of organic compost. Vertical bars in each average point indicate the standard errors

The presence of the organic compost adjusted a quadratic model for the $\mathrm{S}$ doses. The maximum dry weight of seeds per plant $\left(4.38 \mathrm{~g}\right.$ ) was observed for the dose of $66.5 \mathrm{~kg} \mathrm{ha}^{-1}$ of $\mathrm{S}$. For higher S doses; there was a marked decrease in dry seed weight. For the highest $\mathrm{S}$ dose $\left(180 \mathrm{~kg} \mathrm{ha}^{-1}\right)$ presented $2.61 \mathrm{~g} \mathrm{plant}^{-1}$, which was lower than in the treatment without application of $\mathrm{S}$ in topdressing $\left(0 \mathrm{~kg} \mathrm{ha}^{-1}\right): 3.85 \mathrm{~g} \mathrm{plant}^{-1}$.

Therefore, the excess of S (provided by the organic compost plus high doses of ammonium sulfate in topdressing) was harmful to radish and reduced the seed dry weight per plant. On the other hand, in the case of lack of organic compost, S should be applied (topdressing fertilization), as it favored a linear increase of the seed production. In broccoli, Corrêa et al. (2017) also reported a linear increase of the seed production in superior $\mathrm{S}$ doses in the absence of organic compost before planting. Bardiviesso (2018) observed a quadratic effect for the production of zucchini (Cucurbita pepo L.) seeds as a function of the application of $S$ in topdressing fertilization, confirming the importance of this macronutrient in the production of Brassicaceae seeds.

The mineralization organic compost applied $\left(50\right.$ ton $^{-1} \mathrm{ha}^{-1}$ ) represents a great potential for $\mathrm{S}$ release $(0.4 \%)$ to soil solution, and up to $156 \mathrm{~kg} \mathrm{ha}^{-1}$ of $\mathrm{S}$ could be available to plant's absorption. According to Furtini Neto et al. (2001), the availability of S is closely related to 
the soil organic matter content; however, it is not possible to be sure that all $\mathrm{S}$ present in the organic compost will be readily available to the plants. This $S$ availability is regulated by microorganisms that perform the decomposition of the organic matter, besides being dependent on several factors, such as temperature, soil air circulation, and humidity (Monsalve et al., 2017).

Yamada et al. (2007) reported that the $\mathrm{S}$ absorption is directly linked to that of $\mathrm{N}$, and when the former is in excess, reduction occurs in production, probably due to toxicity; however, so far there are no studies about this probable toxicity. Sulfur is needed for the maintenance of plant metabolism (Marschner, 2012) and is an essential component of the enzymes involved in the reduction and assimilation of $\mathrm{N}$ (Capaldi et al., 2015; Geng et al., 2016).

The application of organic compost increased the dry weight of seeds per plant when $S$ was not applied in topdressing, as well as in the lowest $\mathrm{S}$ dose $\left(60 \mathrm{~kg} \mathrm{ha}^{-1}\right)$ (Table 1), with increases of $73.4 \%$ and $53.2 \%$, respectively, in relation to non-application of organic compost. At the highest dose $\left(180 \mathrm{~kg} \mathrm{ha}^{-1}\right.$ of $\left.\mathrm{S}\right)$, the application of organic compost reduced the dry weight of seeds per plant by $33.8 \%$ when compared to the absence of organic compost, confirming the deleterious effect of excess $\mathrm{S}$ (high $\mathrm{S}$ dose in topdressing fertilization with organic compost before planting).

Table 1. Radish seeds dry weight with or without organic compost and dosses of sulfur

\begin{tabular}{|c|c|c|}
\hline \multirow{2}{*}{$\begin{array}{l}\text { S doses } \\
\left(\mathrm{kg} \mathrm{ha}^{-1}\right)\end{array}$} & \multicolumn{2}{|c|}{ Organic compost } \\
\hline & Without & With \\
\hline & \multicolumn{2}{|c|}{$\left(\right.$ g plant $\left.^{-1}\right)$} \\
\hline 0 & $2.22 \mathrm{~b}$ & $3.85 \mathrm{a}$ \\
\hline 60 & $3.01 \mathrm{~b}$ & $4.61 \mathrm{a}$ \\
\hline 120 & $3.52 \mathrm{a}$ & $3.55 \mathrm{a}$ \\
\hline 180 & $3.94 \mathrm{a}$ & $2.61 \mathrm{~b}$ \\
\hline
\end{tabular}

Averages followed by the same letter in lines, for each $\mathrm{S}$ dose, do not differ by the Tukey test $(\mathrm{p}<0.05)$.

Several authors have demonstrated a positive effect of organic fertilization, with an increase in seed production of several vegetable species (Alves et al., 2005; Rech et al., 2006; Magro et al., 2010; Quadros et al., 2012; Corrêa et al., 2017; Lana et al., 2020). According to Mahrous et al. (2015), the use of organic compost also reduces the application of synthetic fertilizers, contributing to the conservation of natural resources.

It should be emphasized that at the beginning of the reproductive phase, the nutritional 
requirement for most species becomes more intense, being more critical in seed formation when a considerable amount of nutrients is needed (Carvalho and Nakagawa, 2012). Thus, fertilization with organic compost, which presents the slow release of nutrients to the plant, great $\mathrm{C}: \mathrm{N}$ ratio, probably had an effect in this stage of seed formation.

\subsection{Content and Accumulation of Macronutrients in Seeds}

Regarding the macronutrient contents in radish seeds, there was no significant effect of the $\mathrm{S}$ doses nor the application of organic compost, averaging 43, 7.0, 9.7, 4.4, 2.7, and $13.5 \mathrm{~g} \mathrm{~kg}^{-1}$ of dry matter for $\mathrm{N}, \mathrm{P}, \mathrm{K}, \mathrm{Ca}, \mathrm{Mg}$, and S, respectively. Kano et al. (2010) observed that the macronutrient contents in lettuce seeds were also not affected by the application of different doses of $\mathrm{K}$ in topdressing; the authors also highlighted that the seeds of some species are like a "filter", without lack or excess of nutrients, unlike the vegetative part where increments of $\mathrm{K}$ were observed as the dose of this nutrient increases, characterizing a luxury absorption observed in vegetative part but not in seeds.

In the present study, even at the highest $S$ dose $\left(180 \mathrm{~kg} \mathrm{ha}^{-1}\right)$ and with the application of organic compost, no change in the seed S content was observed, demonstrating no luxury absorption in the radish seeds. Delouche (1980) points out that the typical response of plants grown on low fertility soil is the reduction in the number of seeds produced and not their quality to provide conditions for the seeds produced to germinate and perpetuate the species.

On the other hand, for the accumulation of all the macronutrients, linear increases (as a function of the $\mathrm{S}$ doses in topdressing) were observed when no organic compost was applied before planting (Figure 1). Increases of 39.1, 6.6, 8.8, 4.0, 2.6, and $11.8 \mathrm{mg} \mathrm{plant}^{-1}$ for each 10 $\mathrm{kg} \mathrm{ha}^{-1}$ of $\mathrm{S}$ for $\mathrm{N}, \mathrm{P}, \mathrm{K}, \mathrm{Ca}, \mathrm{Mg}$, and $\mathrm{S}$ in the radish seeds, resulted in the accumulation of 1697.6, 284.1, 378.7, 176.7, 107.1, and 525.4 mg plant ${ }^{-1}$ at the highest $\mathrm{S}$ dose $\left(180 \mathrm{~kg} \mathrm{ha}^{-1}\right)$, respectively.

The accumulation of all the macronutrients in the radish seeds fitted the quadratic model when organic compost was applied. The maximum nutrient accumulation were 1982.7, 300.4, 426.9, 189.8, 113.2, and 595.2 $\mathrm{mg}$ plant $^{-1}$ for N, P, K, Ca, Mg, and S, respectively (Figure 1). Those nutrient levels were always observed for similar $\mathrm{S}$ doses varying from 54 to $66 \mathrm{~kg} \mathrm{ha}^{-1}$ of $\mathrm{S}$. The maximum macronutrients accumulation tended to decrease in higher $\mathrm{S}$ doses.

Therefore, the accumulation of all macronutrients followed the accumulation of radish seeds dry matter per plant. A linear increment was observed when the organic compost was not applied, and a quadratic adjustment when the organic compost was applied (Figure 1). The lack of differences in the seed nutrient content was expected since the seed extraction is to the weight of dry matter and the concentration of each nutrient.

The decreasing order of macronutrient content and accumulation in the radish seeds was $\mathrm{N}>$ $\mathrm{S}>\mathrm{K}>\mathrm{P}>\mathrm{Ca}>\mathrm{Mg}$. The same order was reported by Cardoso et al. (2016) in cauliflower seeds. Magro et al. (2010), when evaluating the accumulation in broccoli seeds, observed the following order: $\mathrm{N}>\mathrm{S}>\mathrm{P}>\mathrm{K}>\mathrm{Ca}>\mathrm{Mg}$. It stands out as the main similarity among the works is $\mathrm{S}$ being the second most accumulated nutrient, only behind $\mathrm{N}$. This fact is due to the great requirement of this nutrient by the Brassicaceae plant species, which extract substantial 
amounts of $\mathrm{S}$ in relation to other macronutrients (Filgueira, 2013). For the purpose of comparison, Kano et al. (2010) observed the following order of accumulation in the lettuce (Lactuca sativa $\mathrm{L}$.) seeds: $\mathrm{N}>\mathrm{P}>\mathrm{K}>\mathrm{Mg}>\mathrm{Ca}>\mathrm{S}$, where $\mathrm{S}$ was the less accumulated macronutrient, while in zucchini it was the second more accumulated nutrient (Bardiviesso, 2018; Lanna, 2018).

The $\mathrm{N}$ was the nutrient accumulated in greater quantity by the seeds of radish. Similar results were obtained in seeds of lettuce (Kano et al., 2010), broccoli (Magro et al., 2010), cauliflower (Cardoso et al., 2016), and zucchini (Bardiviesso, 2018; Lanna, 2018). Cardoso (2011) reported that the seed accumulation of $\mathrm{N}$ was always greater than that of the other nutrients. This shows the importance of this element $(\mathrm{N})$ in the composition of the seed, usually rich in proteins, besides being a nutrient easily redistributed in the plant to the reproductive parts (Malavolta, 2006). During the seed maturation phase, many nutrients are translocated from the leaves to the reproductive organs. Leaf proteins are degraded, and the $\mathrm{N}$ released $\left(\mathrm{NH}^{4+}\right)$ is reassimilated and converted mainly into the glutamine amide and asparagine. These substances are then translocated to growing plant organs (Souza and Fernandes, 2006), like the seeds.

The $\mathrm{S}$ was the second most accumulated nutrient in the radish seeds, independently of the treatment, even without organic compost and without $\mathrm{S}$ applied in the topdressing fertilization, confirming the importance of this nutrient for the formation of radish seeds, as well as other Brassicaceas. In cauliflower, of the total S accumulated in the plant, $30 \%$ was in the seeds, almost the same rate as $\mathrm{N}$ (Cardoso et al., 2016).

Potassium was the third most accumulated macronutrient in the seeds. Normally $\mathrm{N}$ and $\mathrm{K}$ are the most accumulated nutrients in plants (Malavolta, 2006) however, in the Brassicaceae seeds $\mathrm{K}$ is less accumulated than $\mathrm{S}$. Besides its importance, the $\mathrm{K}$ presents great mobility in the plant, which facilitates the translocation to the seeds. Unlike N, K is not part of any organic compound in the plant; according to Kiehl (2008) and Magro et al., (2012), potassium is the most readily available to plants with organic fertilization. However, the lack of fertilization with organic compost did not affect the accumulation of $\mathrm{K}$ in the seeds.

Phosphorus was the fourth most accumulated nutrient in radish seeds. During the development of the plants, the phosphorus presents great mobility, with greater concentration in the flowers and fruits (Araújo et al., 2015). In plants, phosphorus has several functions, such as root development, which favors flowering and seed formation (Malavolta, 2006). Together with other nutrients, it is stored in the salts of phytic acid, constituting phytin, which is the main form of storage of phosphorus in the seeds and has an important function during germination (Carvalho and Nakagawa, 2012).

Calcium was only the fifth nutrient in order of accumulation in radish seeds, despite its importance in the plant. One of the functions of $\mathrm{Ca}$ is in the formation of calcium pectate, present in the walls of plant cells, as well as in pollen germination, pollen tube formation and seed development (Malavolta et al., 1997; Faquin, 2005). However, its redistribution to seeds is very low (Marschner, 2012; Araújo et al., 2015), because, according to Kano et al. (2011), its accumulation in the seeds occurs almost exclusively by the absorption and transport 
during the formation of the seeds. It is not translocated from the leaves to the reproductive organs and seeds. In cauliflower, of the total $\mathrm{Ca}$ accumulated in the plant, only $2.8 \%$ was in the seeds (Cardoso et al., 2016).

Magnesium was the macronutrient less accumulated in radish seeds. The same was reported by Bardiviesso (2018) and Lanna (2018) in zucchini seeds. In cauliflower, only $14.8 \%$ of the accumulated $\mathrm{Mg}$ in the plant was found in the seeds (Cardoso et al., 2016), confirming that this nutrient is mostly found in other organs of the plant, especially in the leaves, because it is an important nutrient in the composition of chlorophyll. In the seeds, $\mathrm{Mg}$ enters the composition of phytin salts, which are forms of $\mathrm{P}$ storage in the seeds. During seed germination, the redistribution of $\mathrm{P}$ and $\mathrm{Mg}$ to various parts of the growing plant occurs to contribute to the formation of new tissues (Neptune,1986; Vitti et al., 2006).

For most species, $\mathrm{S}$ is a secondary macronutrient in seed formation (Cardoso, 2011). Still, for Brassiaceae species, $\mathrm{S}$ is the second most accumulated nutrient in seeds, and is related to seed production improvements (Corrêa et al., 2016). Considering the importance of $S$ for radish seed production, the application and reposition to every cropping cycle must be done, but it is necessary to avoid excess. In the absence of organic compost before planting $\mathrm{S}$ can be applied until $180 \mathrm{~kg} \mathrm{ha}^{-1}$ of $\mathrm{S}$. On the other hand, if organic compost is applied before radish planting $\left(50 \mathrm{t} \mathrm{ha}^{-1}\right)$, up to $66 \mathrm{~kg} \mathrm{ha}^{-1}$ of $\mathrm{S}$ is recomended.

The results observed in the present study indicate a decreasing order of macronutrient accumulations in the radish seeds: $\mathrm{N}>\mathrm{S}>\mathrm{K}>\mathrm{P}>\mathrm{Ca}>\mathrm{Mg}$; this order also indicated that the macronutrients were not affected by the $\mathrm{S}$ doses or the organic compost application according to literature available. Our results also indicated that high $\mathrm{S}$ doses resulted in great seed dry weight and accumulation of macronutrients when no organic compost was applied; but, in low $\mathrm{S}$ doses (up to $66 \mathrm{~kg} \mathrm{ha}^{-1}$ ), the application of organic compost increased seed dry weight and accumulation of macronutrients in radish seeds.

\section{Conclusions}

The sulfur supplementation or organic compost application was not sufficient to affect the contents of macronutrients in radish seeds.

When organic compost was not applied, the sulfur supplementation generated great radish seed dry weight and the accumulation of macronutrients. Conversely, the application of organic compost increased the radish seed dry weight and the accumulation of macronutrients in low sulfur concentrations - up to $66 \mathrm{~kg} \mathrm{ha}^{-1}$ of $\mathrm{S}$.

The decreasing order of macronutrient content and accumulation by the radish seeds was $\mathrm{N}>$ $\mathrm{S}>\mathrm{K}>\mathrm{P}>\mathrm{Ca}>\mathrm{Mg}$.

\section{Acknowledgments}

The authors would thank the Coordination for the Improvement of Higher Education Personnel (CAPES) and the National Council for Scientific and Technological Development (CNPq) for the scholarships. 


\section{References}

Alvarez-Venegas, V. H., Roscoe, R., Kurihara, C. H., \& Pereira, N. F. (2007). Enxofre. In: R. F. Novais, V. H. Alvarez-Venegas, N. F. Barros, R. L. F. Fontes, R. B. Cantarutti, \& J. C. L. Neves (Eds), Fertilidade do solo (pp. 595-646). Viçosa: Sociedade Brasileira de Ciência do Solo.

Alves, E. U., Oliveira, A. P., Riselane, L. A., Sader, R., \& Alves, A. U. (2005). Yield and physiological quality of coriander seeds cultivated with manure and mineral fertilizer. Revista Brasileira de Sementes, 27, 132-137. https://doi.org/10.1590/S0101-31222005000100016

Araújo, H. S., Cardoso, A. I. I., Oliveira Júnior, M. X., \& Magro, F. O. (2015). Macronutrients content and extraction in zucchini plants in function of potassium top dressing levels. Revista Brasileira de Ciências Agrárias, 10, 389-395. https://doi.org/10.5039/agraria.v10i3a4937

Bardiviesso, E. M. (2018). Sulfur and organic compost in production and seed quality and accumulation of macronutrients in ripe fruits and seeds of zucchini. Master thesis. Faculdade de Ciências Agronômicas - Unesp, Campus de Botucatu. Accessed July 31, 2021. http://hdl.handle.net/11449/153760

Caires, E. F., \& Fonseca, A. F. (2000). Soybean nutrient uptake as a function of liming surface application, under a no-tillage system. Bragantia, 59, 213-220. https://doi.org/10.1590/S0006-87052000000200013

Capaldi, F. R., Gratão, P. L., Reis, A. R., Lima, L. W., \& Azevedo, R. A. (2015). Sulfur metabolism and stress defense responses in plants. Tropical Plant Biology, 8, 60-73. https://doi.org/10.1007/s12042-015-9152-1

Cardoso, A. I. I. (2011). Nutrição e adubação em campos de produção de sementes de hortaliças. In: W. M. Nascimento (Ed), Hortaliças: tecnologia de produção de sementes (pp. 109-134). Brasília: Embrapa Hortaliças.

Cardoso, A. I. I., Claudio, M. T. R., Nakada-Freitas, P. G., Magro, F. O., \& Tavares, A. E. B. (2016). Phosphate fertilization over the accumulation of macronutrients in cauliflower seed production. Horticultura Brasileira, $\quad 34, \quad$ 196-201. https://doi.org/10.1590/S0102-053620160000200008

Cardoso, A. I. I., Ferreira, K. P., Vieira Júnior, R. M., \& Alcarde, C. (2011). Changes in soil properties managed with organic compost and its effect on lettuce seed quality. Horticultura Brasileira, 29, 594-599. https://doi.org/10.1590/S0102-05362011000400025

Carvalho, J. B. M., Nascimento, J. M., Alvarenga, C. B., Maciel, G. M., Silva, A. A., \& Borba, M. E. A. (2017). Production and physiological quality of lettuce seeds grown with organic and mineral fertilization. Revista de Ciências Agrárias - Amazonian Journal of Agricultural and Environmental Sciences, 60, 70-76. https://doi.org/10.4322/rca.2424

Carvalho, N. M., \& Nakagawa, J. (2012). Seeds: science, technology and production. 5th ed. Jaboticabal: FUNEP. p. 88.

Corrêa, C. V., Gouveia, A. M. S., Lanna, N. B. L., Martins, B. N. M., Tavares, A. E. B., Mendonça, V. Z., Cardoso, A. I. I., \& Evangelista, R. M. (2017). Sulphur (S) topdressing and organic compost in production, quality and nutrients accumulation of broccoli seeds at planting time. Australian Journal of Crop Science, 11, 542-547. https://doi.org/10.21475/ajcs.17.11.05.p331

Cunha, A. R., \& Martins, D. (2009). Climatic classification for the districts of Botucatu and 
São Manuel, SP. Irriga, 14, 1-11. https://doi.org/10.15809/irriga.2009v14n1p01

Delouche, J. C. (1980). Environmental effects on seed development and seed quality. Hortscience, 15, 775-780.

Faquin V (2005). Nutrição mineral de plantas. UFLA, Lavras: FAEPE. p. 183.

Fernandes MS (2006). Mineral plant nutrition. SBCS, UFV Viçosa: Viçosa. p. 432.

Ferreira, D. F. (2011). Sisvar: a computer statistical analysis system. Ciência e Agrotecnologia, 35, 1039-1042. https://doi.org/10.1590/S1413-70542011000600001

Filgueira, F. A. R. (2013). Novo manual de olericultura: agrotecnologia moderna na produção e comercialização de hortaliças. 3. ed. rev. UFV Viçosa: Viçosa. p. 421.

Furtini Neto, A. E., Vale, F. R., Resende, A. V., Guilherme, L. R. G., \& Guedes, G. A. A. (2001). Fertilidade do solo. UFLA Lavras: FAEPE. p. 252.

Geng, J., Ma, Q., Chen, J., Zhang, M., Li, C., Yang, Y., Liu, Z. (2016). Effects of polymer coated urea and sulfur fertilization on yield, nitrogen use efficiency and leaf senescence of cotton. Field Crops Research, 187, 87-95. https://doi.org/10.1016/j.fcr.2015.12.010

Kano, C., Cardoso, A. I. I., Villas Bôas, R. L. (2010). Macronutrient content in lettuce affected by potassium side dressing. Horticultura Brasileira, 28, 287-291. https://doi.org/10.1590/s0102-05362010000300008

Kano, C., Cardoso, A. I. I., Villas Bôas, R. L., Higuti, A. R. O. (2011). Lettuce seed germination from plant cultivated with different phosphorus levels. Semina - Ciências Agrárias, 32, 591-598. https://doi.org/10.5433/1679-0359.2011v32n2p591

Kiehl, E. J. (2008). Adubação orgânica: 500 perguntas e respostas. $2^{\text {nd }}$ ed. Piracicaba: Degaspari. p. 217.

Lanna, N. B. L., Bardiviesso, E. M., Tavares, A. E. B., Silva, P. N. L., Nakada-Freitas, P. G., Noda, S. B. H., \& Cardoso, A. I. I. (2020). Castor bean cake in top-dressing application as a source of nitrogen on the production and quality of zucchini organic seeds. Bioscience Journal, 36(Supl 1), 130-142. https://doi.org/10.14393/BJ-v36n0a2020-53563

Magro, F. O., Arruda, N., Casa, J., Salata, A. C., Cardoso, A. I. I., \& Fernandes, D. M. (2010). Organic compost in broccoli seed yield and quality. Ciência e Agrotecnologia, 34, 596-602. https://doi.org/10.1590/S1413-70542010000300010

Magro, F. O., Cardoso, A. I. I., \& Fernandes, D. M. (2012). Organic compost in physiological potential of broccoli seeds after storage. Semina - Ciências Agrárias, 33, 1033-1040. https://doi.org/10.5433/1679-0359.2012v33n3p1033

Mahrous, N. M., Safina, S. A., Abo Taleb, H. H., \& El-Sayed El-Behlak, S. M. (2015). Integrated use of organic, inorganic and bio fertilizers on yield and quality of two peanut (Arachis hypogaea L.). cultivars grown in a sandy saline soil. American-Eurasian Journal of $\begin{array}{lllll}\text { Agricultural } \quad \& \quad \text { Environmental } & \text { Sciences, } & 15, & 1067-1074 .\end{array}$ http://dx.doi.org/10.5829/idosi.aejaes.2015.15.6.12690

Malavolta E (2006). Manual de nutrição mineral de plantas. São Paulo: Ceres. p. 631.

Malavolta, E., Vitti, G. C., \& Oliveira, A. S. (1997). Avaliação do estado nutricional das plantas, princípios e aplicações. $1^{\text {st }}$ ed. Piracicaba: Portafós. p. 319.

Marschner, P. (2012). Marschner's mineral nutrition of higher plants. $3^{\text {rd }}$ ed. London: Academic Press. p. 672.

Melo, L., Avanzi, J., Carvalho, R., Souza, F., Pereira, J. L., Mendes, A., \& Macêdo, G. (2011). 
Maize nutrition and dry matter yield under liming and sulfur fertilization. Pesquisa Agropecuária Tropical, 41, 193-199. https://doi.org/10.5216/pat.v41i2.8685

Monsalve, O., Gutierrez, J., \& Cardona, W. (2017). Factors involved in the process of nitrogen mineralization when organic amendments are added to a soil. A review. Revista Colombiana de Ciencias Hortícolas, 200-209. https://doi.org/10.17584/rcch.2017v11i1.5663

Neptune, A. M. L. (1986). Aplicação de calcário em culturas forrageiras. In: FEALQ, editor. Pastagens - fundamentos de exploração racional (pp. 74-107). Piracicaba: FEALQ.

Pereira, C. S., De Freitas, A. A., Chapla, M. V., \& Lange, A. (2016). Potassium doses with the presence of sulphur in soybean crop. Global Science and Technology, 9, 22-32. https://doi.org/10.1590/1807-1929/agriambi.v22n2p90-94

Quadros, B. R., Corrêa, C. V., Magro, F. O., \& Cardoso, A. I. I. (2012). Influence of organic compost and phosphorus on lettuce seeds. Semina - Ciências Agrárias, 33, 2511-2518. https://doi.org/10.5433/1679-0359.2012v33Sup11p2511

Raij, B. Van, Cantarella, H., Quaggio, J. A., \& Furlani, A. M. C. (1997). Recomendações de adubação e calagem para o estado de São Paulo. IAC - Boletim Técnico, 100. Campinas: Instituto Agronômico - Fundação IAC. p. 285.

Rech, E. G., Franke, L. B., \& Barros, I. B. I. (2006). Organic and mineral fertilization on the production of zucchini seeds. Revista Brasileira de Sementes, 28, 110-116. https://doi.org/10.1590/S0101-31222006000200014

Rheinheimer, D. S., Alvarez, J. W. R., Osorio Filho, B. D., Silva, L. S., \& Bortoluzzi, E. C. (2005). Crop responses for sulphur application and sulfate levels in a sandy soil under no-tillage. Ciência Rural, 35, 562-569.

Souza, S. R., \& Fernandes, M. S. (2006). Nitrogênio. In: M. S. Fernandes (Ed.). Nutrição Mineral de Plantas (pp. 215-252). Viçosa: SBCS, UFV, DPS.

Sun, L., Yang, J., Fang, H., Xu, C., Peng, C., Huang, H., Lu, L., Duan, D., Zhang, X., \& Shi, J. (2017). Mechanism study of sulfur fertilization mediating copper translocation and biotransformation in rice (Oryza sativa L.) plants. Environmental Pollution, 26, 426-434.

Tiecher, T., Santos, D. R. A., Rasche, J. W., Mallmann, F. J. K., Piccin, R., \& Brunetto, G. (2013). Crops response to sulfur fertilization and atmospheric deposition. Revista Ceres, 60, 420-427. https://doi.org/10.1590/S0034-737X2013000300016

Vitti, G. C., Lima, E., \& Cicarone, F. (2006). Cálcio, magnésio e enxofre. In: M. S. Fernandes (Ed.). Nutrição Mineral de Plantas (pp. 299-325). Viçosa: SBCS, UFV, DPS.

Yamada, T., Abdalla, S. R. S., \& Vitti, G. C. (2007). Nitrogen and sulfur in Brazilian agriculture. Piracicaba: INPI-Brasil. p. 722.

\section{Copyright Disclaimer}

Copyright for this article is retained by the author(s), with first publication rights granted to the journal.

This is an open-access article distributed under the terms and conditions of the Creative Commons Attribution license (http://creativecommons.org/licenses/by/4.0/). 